Vol. 5 (1996): 557-565.

\title{
Effects of feed processing on the apparent ileal digestibility of amino acids in pig diets containing wheat bran or wheat middlings
}

Jarmo Valaja

Agricultural Research Centre of Finland, Institute of Animal Production, FIN-31600 Jokioinen, Finland,

e-mail: jarmo.valaja@mtt.fi

Hilkka Siljander-Rasi

Agricultural Research Centre of Finland, Swine Research Station, FIN-05840 Hyvinkää, Finland

Markku Mäkinen

Agricultural Research Centre of Finland, Institute of Animal Production, FIN-31600 Jokioinen, Finland

The effects of feed processing on the apparent ileal digestibility of amino acid and the utilisation of nitrogen $(\mathrm{N})$ in diets containing wheat by-products were studied in five castrated male pigs (live weight $40-109 \mathrm{~kg}$ ). A T-cannula was surgically fitted into the caecum of the pigs at a live weight of $27 \mathrm{~kg}$ using the steered ileo-caecal valve technique. The experiment was conducted with a $6 \mathrm{x}$ 5 cyclic change-over design in which six diets were arranged $2 \times 3$ factorially. The corresponding factors were type of wheat by-product in the diets: wheat bran $(152 \mathrm{~g} / \mathrm{kg})$ or wheat middlings $(328 \mathrm{~g} / \mathrm{kg})$, and method of feed processing: steam pelleting, expanding or extrusion. The other dietary feed ingredients were barley and soya bean meal.

The feed-processing method or dietary wheat by-product had no effect on the apparent ileal digestibility of amino acids and crude protein. The pigs on diets containing wheat middlings tended to retain more $\mathrm{N}$ per intake $(\mathrm{p}<0.10)$ than did those on wheat bran diets. The wheat middlings diets also tended to have higher biological values than did the wheat bran diets $(\mathrm{p}<0.10)$. Further, daily $\mathrm{N}$ retention tended to be better with expanding than with pelleting $(\mathrm{p}<0.10)$. The $\mathrm{N}$ retention differences were mainly caused by the differences in $\mathrm{N}$ intakes of the treatments.

In conclusion, feed processing at a moderate temperature or wheat by-product in the diets had no influence on the apparent ileal digestibility of amino acids.

Key words: pelleting, expanding, extrusion, protein, swine, nitrogen utilisation, wheat by-product 


\section{AGRICULTURAL AND FOOD SCIENCE IN FINLAND}

Valaja, J. et al. Effects of feed processing on the apparent ileal digestibility of amino acids

\section{Introduction}

Pressurized hydrothermal feed processing methods such as pelleting, expanding and extrusion are commonly used in the feed industry to improve the nutritive value and hygienic quality of feed ingredients or compounds. The processing treatments are claimed to rupture the cellwall matrix and liberate intracellular nutrients available for endogenous enzymes. Improvements in protein and amino acid digestibility have usually been only minor or non-existent (Skoch et al. 1983, Fadel et al. 1988, Sauer et al. 1990, Herkelman et al. 1990, Laurinen et al. 1995). Processing has, however, increased the protein digestibility of certain feeds, e.g. beans, by inactivating antinutritional substances (Van der Poel et al. 1991). High temperature feed processing can also cause Maillard reactions, which depress the digestibility and utilisation of lysine in the feeds (Björk and Asp 1983).

Wheat bran and wheat middlings are wheat milling by-products obtained from the milling process either separately or in combination. Wheat bran, derived mainly from partly lignified pericarp and testa layers of the grain, contains high amounts of insoluble dietary fibre. Wheat middlings, however, consist of proteinrich aleurone layers and parts of endosperm, and contain more unlignified soluble dietary fibre (Bach Knudsen and Hansen 1991). Dietary inclusion of fibre-rich wheat bran has decreased the feed retention time from mouth to anus and depressed the digestibility of nutrients including protein (Stanogias and Pearce 1985).

The effects of the different feed-processing methods on the apparent ileal digestibility of amino acids have not been studied very widely (Herkelman et al. 1990, Van der Poel et al. 1990). Moreover, expanding is a fairly new processing method and no data are yet available on its effects on the ileal digestibility of amino acids.

The purpose of this study was to compare the effects of pelleting, expanding or extrusion on the apparent ileal digestibility of protein and amino acids in diets containing either wheat bran or wheat middlings. The total tract digestibility of protein and the utilisation of nitrogen were also studied.

\section{Material and methods}

\section{Animals and experimental procedure}

The study was conducted on five castrated male pigs (Finnish Yorkshire) with an average live weight of 40.3 to $109.1 \mathrm{~kg}$. A silicone T-cannula was surgically fitted into the caecum of the pigs at an average live weight of $27.3 \mathrm{~kg}$ with the steered ileo-caecal valve (SICV) technique (Mroz et al. 1994). This technique allows ileal digesta to be collected quantitatively via a valvesteering system. The animals were placed individually in pens of $1.43 \mathrm{~m} \times 1.23 \mathrm{~m}$ with a slatted plastic floor and kept there throughout the study. During the 2-week post-operative period feed allowance was gradually increased to the experimental level.

The experiment was conducted with a $6 \times 5$ cyclic change-over design in which six experimental treatments were arranged $2 \times 3$ factorially. The corresponding factors were wheat byproduct in the diet: wheat bran or wheat middlings, and the method of feed processing: steam pelleting, expanding or extrusion. The five 15day experiment periods comprised preliminary feeding for 7 days followed by 5 days of total collection of faeces and urine (Table 1). Faeces were collected with plastic bags attached around the anus with glued adhesive tape and snap-fasteners (Van Kleef et al. 1994). The plastic collection bags were replaced with new ones after the pigs had defecated. The faeces were collected and weighed and frozen at $-20^{\circ} \mathrm{C}$. Ileal digesta was collected continuously during two 12 $\mathrm{h}$ periods between 06.00 and $18.00 \mathrm{~h}$ at an interval of 3 days into a plastic bag attached to the barrel of the cannula. The bags were changed at least hourly. The digesta was weighed and frozen immediately at $-20^{\circ} \mathrm{C}$. Urine was collected 


\section{AGRICULTURAL AND FOOD SCIENCE IN FINLAND}

Vol. 5 (1996): 557-565.

Table 1. Scheme of experimental procedure.

\begin{tabular}{ll}
\hline Day & \\
\hline $1-7$ & $\begin{array}{l}\text { Preminary feeding } \\
8-12\end{array}$ \\
13 & $\begin{array}{l}\text { Total collection of faeces and urine } \\
\text { Continuous collection of ileal digesta for } 12 \mathrm{~h}\end{array}$ \\
14 & (between 06.00 and $18.00 \mathrm{~h}$ ) \\
15 & $\begin{array}{l}\text { Continuous collection of ileal digesta for } 12 \mathrm{~h} \\
\text { (between } 06.00 \text { and } 18.00 \mathrm{~h} \text { ) }\end{array}$ \\
\hline
\end{tabular}

daily into $40 \mathrm{ml}$ of $10 \mathrm{~N} \mathrm{H}_{2} \mathrm{SO}_{4}$, sampled and frozen at $-20^{\circ} \mathrm{C}$.

\section{Experimental feeds and feeding}

Isoenergetic experimental feeds were formulated to contain similar amounts of crude protein, lysine and neutral detergent fibre (NDF). The feeds, which consisted of barley, soya bean meal, vegetable oil and either wheat bran or wheat middlings (Table 2), were supplemented with minerals and vitamins and $\mathrm{L}$ lysine $\mathrm{HCl}$ and $\mathrm{DL}$ methionine to meet the requirements of growing pigs (Tuori et al. 1995). The two feed mixtures were either steam pelleted, expanded or extruded to form the six experimental feeds. The feeds were steam pelleted using $1.2 \%$ steam at a temperature of $+62^{\circ} \mathrm{C}$. Before expansion with the annular gap expander (Amandus Kahl Nachf. $\mathrm{GmbH})$, the feeds were preconditioned for $25 \mathrm{~min}$ at $+85^{\circ} \mathrm{C}$ with $1.2 \%$ addition of water. The temperatures during expansion were +100 $105^{\circ} \mathrm{C}$ and the pressure was 10 bar. During the extrusion phase with a twin-screw extruder (Clextral S.A.), the barrel temperature was $+150^{\circ} \mathrm{C}$ and the mass temperature before die was $+120^{\circ} \mathrm{C}$. In the course of processing, moisture was added in the form of water and steam (9$13 \%$ ) and the pressure was 40 bar.

The pigs were fed twice daily, at 06.00 and 18.00. The daily feeding scale was 2.7 times the assumed maintenance energy requirement (0.5 MJ ME/kg W ${ }^{0.75}$; from 24.6 to $38.4 \mathrm{MJ} \mathrm{ME/}$ day). The daily ratio was adjusted in each peri- od according to the body weight. During the feeding, water was added to the diets in a ratio of 1.5:1 and was also freely available from lowpressure drinking nipples. Chromium $(\mathrm{Cr})$, ytterbium ( $\mathrm{Yb})$ and cobalt $(\mathrm{Co})$ were used as indigestible markers for the determination of nutrient digestibilities. Cr-mordanted straw (73 g $\mathrm{Cr} / \mathrm{kg} \mathrm{DM}$ ) was added to the diets at a level of $2 \mathrm{~g} / \mathrm{kg}$ feed (Udén et al. 1980). Yb-acetate and a lithumCo-EDTA complex were dissolved in water and sprayed onto the surface of the barley in a batchmixer. The barley was dried and ground and fed to the pigs at a level of $50 \mathrm{~g} / \mathrm{kg}$ feed.

\section{Analytical procedure}

The feed, faeces and ileal digesta samples were freeze-dried and ground through 1-mm mash before analysis. Feeds, ileal digesta samples and faeces were analysed with the standard methods (AOAC 1984). Ether extract was determined after acid hydrolysis. The NDF content of the feeds was analysed with the method of Robertson and van Soest (1981). The amino acids in feeds and ileal digesta samples were determined with a Beckman 6300 amino acid analyser after $23 \mathrm{~h}$ hydrolysis with $6.0 \mathrm{~N} \mathrm{HCl}$. Methionine and cystine were determined after oxidation to methionine sulphone and cysteic acid. $\mathrm{Cr}, \mathrm{Yb}$ and $\mathrm{Co}$ were analysed by atomic absorption spectrometry. All analyses were performed in duplicate except that of markers.

Total tract digestibility values were calculated from the total collection of faeces. Ileal digestibility values were calculated from the $\mathrm{Cr}$ ratio of feeds and ileal digesta because the faecal recovery rate of $\mathrm{Cr}$ was the closest to $100 \%$ (faecal recovery rate: $\mathrm{Cr}$ 95.3\% (SE 2.49), Yb $114.9 \%$ (SE 3.31), Co 65.8\% (SE 1.79)). The data were subjected to analysis of variance using the GLM procedure of SAS (1985). The model was:

$\mathrm{y}_{\mathrm{ijk} \mid}=\mu+\mathrm{p}_{\mathrm{i}}+\mathrm{a}_{\mathrm{j}}+\mathrm{d}_{\mathrm{k}}+\mathrm{e}_{\mathrm{ijk} \mathrm{l}}$

where $y_{i j k \mathrm{l}}$ is the dependent variable; $\mu$ is the overall mean; $p_{i}$ is the effect of the period; $a_{j}$ is 
Valaja, J. et al. Effects of feed processing on the apparent ileal digestibility of amino acids

Table 2. Dietary ingredients $(\mathrm{g} / \mathrm{kg})$ and chemical composition of diets ( $\mathrm{g} / \mathrm{kg} \mathrm{DM})$.

\begin{tabular}{|c|c|c|c|c|c|c|}
\hline Diet & 1 & 2 & 3 & 4 & 5 & 6 \\
\hline Wheat by-product & WB & WM & WB & WM & WB & WM \\
\hline Processing & $\mathrm{P}$ & $\mathrm{P}$ & EXP & EXP & $\mathrm{EX}$ & EX \\
\hline Barley & 633 & 523 & 633 & 523 & 633 & 523 \\
\hline Soya bean meal & 152 & 96 & 152 & 96 & 152 & 96 \\
\hline Wheat bran & 152 & - & 152 & - & 152 & - \\
\hline Wheat middlings & - & 328 & - & 328 & - & 328 \\
\hline Vegetable oil & 30 & 20 & 30 & 20 & 30 & 20 \\
\hline L-lysine $\mathrm{HCl}$ & 2 & 2.5 & 2 & 2.5 & 2 & 2.5 \\
\hline DL methionine & 0.6 & 0.5 & 0.6 & 0.5 & 0.6 & 0.5 \\
\hline Minerals and vitamins & 30.3 & 30.3 & 30.3 & 30.3 & 30.3 & 30.3 \\
\hline \multicolumn{7}{|l|}{ Analysed composition } \\
\hline Dry matter, g/kg & 897.0 & 897.1 & 892.9 & 888.8 & 943.5 & 946.2 \\
\hline Organic matter & 940.5 & 943.7 & 948.7 & 948.0 & 948.8 & 948.9 \\
\hline Ash & 59.5 & 56.3 & 51.3 & 52.0 & 51.2 & 51.1 \\
\hline Crude protein & 181.8 & 157.3 & 187.1 & 183.1 & 182.2 & 176.4 \\
\hline Ether extract & 69.8 & 62.1 & 70.5 & 67.0 & 74.3 & 65.4 \\
\hline Crude fibre & 57.4 & 63.9 & 55.3 & 61.3 & 58.6 & 55.7 \\
\hline NDF & 222.2 & 260.6 & 205.6 & 248.0 & 228.8 & 250.0 \\
\hline $\mathrm{N}$-free extracts & 631.6 & 660.4 & 635.8 & 636.6 & 633.7 & 651.5 \\
\hline \multicolumn{7}{|l|}{ Essential amino acids } \\
\hline Arginine & 10.4 & 8.9 & 10.9 & 8.9 & 10.9 & 10.0 \\
\hline Histidine & 4.2 & 3.6 & 4.4 & 4.2 & 4.3 & 4.0 \\
\hline Isoleucine & 6.2 & 4.9 & 6.5 & 6.0 & 6.7 & 5.9 \\
\hline Leucine & 11.8 & 9.6 & 12.2 & 11.4 & 12.7 & 11.1 \\
\hline Lysine & 9.4 & 8.6 & 9.8 & 9.5 & 10.4 & 9.2 \\
\hline Methionine & 3.3 & 3.0 & 3.2 & 3.1 & 3.6 & 3.4 \\
\hline Phenylalanine & 8.1 & 6.8 & 8.6 & 7.9 & 8.7 & 7.5 \\
\hline Threonine & 6.1 & 5.0 & 6.2 & 5.9 & 6.6 & 5.9 \\
\hline Valine & 7.7 & 6.5 & 7.8 & 7.6 & 8.2 & 7.3 \\
\hline \multicolumn{7}{|c|}{ Non-essential amino acids } \\
\hline Alanine & 7.8 & 6.8 & 7.8 & 7.8 & 7.9 & 7.5 \\
\hline Aspargic acid & 14.4 & 10.9 & 15.2 & 13.9 & 15.2 & 13.5 \\
\hline Cystine & 3.1 & 3.1 & 3.3 & 3.1 & 3.2 & 3.1 \\
\hline Glutamic acid & 34.8 & 30.4 & 37.3 & 34.5 & 36.3 & 34.3 \\
\hline Glycine & 8.1 & 6.9 & 7.8 & 7.6 & 8.1 & 7.5 \\
\hline Serine & 7.9 & 6.5 & 8.3 & 7.7 & 8.5 & 7.5 \\
\hline Tyrosine & 4.6 & 3.7 & 4.8 & 4.4 & 5.0 & 4.2 \\
\hline
\end{tabular}

$\mathrm{WB}=$ wheat bran, $\mathrm{WM}=$ wheat middlings, $\mathrm{P}=$ pelleted, $\mathrm{EXP}=$ expanded, $\mathrm{EX}=$ extruded and $\mathrm{NDF}=$ neutral detergent fibre.

the effect of the animal; $d_{k}$ is the effect of the diet; and $e_{i j \mathrm{kl}}$ is a normally distributed random variable. Five orthogonal contrasts were formed to test the following effects: $\mathrm{C} 1$ : wheat bran diets vs wheat middlings diets; $\mathrm{C} 2$ : extruder processing vs pelleting and expanding; $\mathrm{C} 3$ : pelleting vs expanding; $\mathrm{C} 4$ : interaction $\mathrm{C} 1{ }^{*} \mathrm{C} 2$; and $\mathrm{C} 5$ : interaction $\mathrm{C} 1 * \mathrm{C} 3$.

\section{Results}

One animal did not recover from the surgical operation and had to be excluded from the experiment. Also, one observation was lacking from the total tract digestibility data because of diet refusals caused by mild fever, and six ob- 


\section{AGRICULTURAL AND FOOD SCIENCE IN FINLAND}

Vol. 5 (1996): 557-565.

Table 3. Effect of feed processing on total tract digestibility of crude protein and apparent ileal digestibility of crude protein and amino acids in diets containing wheat bran or wheat middlings (LS means).

\begin{tabular}{|c|c|c|c|c|c|c|c|c|c|c|c|c|}
\hline Diet & 1 & 2 & 3 & 4 & 5 & 6 & SEM $^{2}$ & \multicolumn{5}{|c|}{ Statistical significance of effect } \\
\hline Wheat by-product & WB & WM & WB & WM & WB & WM & & $\mathrm{Cl}^{1}$ & $\mathrm{C} 2$ & $\mathrm{C} 3$ & $\mathrm{C} 4$ & $\mathrm{C} 5$ \\
\hline Processing & $\mathrm{P}$ & $\mathrm{P}$ & EXP & EXP & EX & EX & & & & & & \\
\hline $\mathrm{n}^{3}$ & 4 & 2 & 3 & 4 & 2 & 4 & & & & & & \\
\hline \multicolumn{13}{|c|}{ Total tract digestibility } \\
\hline Dry matter & 83.0 & 80.3 & 83.1 & 81.5 & 82.5 & 83.0 & 0.33 & $* *$ & * & ns & $* *$ & $\mathrm{~ns}$ \\
\hline Crude protein & 84.5 & 83.0 & 83.9 & 83.4 & 84.4 & 84.0 & 0.50 & ns & ns & ns & ns & ns \\
\hline \multicolumn{13}{|l|}{ Ileal digestibility } \\
\hline Dry matter & 69.0 & 66.4 & 69.9 & 67.0 & 67.1 & 66.2 & 1.21 & ns & ns & ns & ns & ns \\
\hline Crude protein & 75.0 & 76.6 & 76.0 & 76.0 & 77.3 & 75.5 & 1.22 & ns & ns & ns & ns & $\mathrm{ns}$ \\
\hline \multicolumn{13}{|c|}{ Essential amino acids } \\
\hline Arginine & 84.1 & 85.1 & 83.8 & 82.9 & 85.5 & 82.8 & 1.05 & ns & ns & ns & ns & ns \\
\hline Histidine & 80.9 & 81.9 & 82.4 & 81.2 & 81.7 & 80.5 & 0.89 & ns & ns & ns & ns & $\mathrm{ns}$ \\
\hline Isoleucine & 77.2 & 78.8 & 78.2 & 77.7 & 81.1 & 78.6 & 1.13 & ns & ns & ns & ns & $\mathrm{ns}$ \\
\hline Leucine & 79.0 & 81.5 & 79.9 & 79.7 & 82.8 & 79.9 & 0.94 & ns & ns & ns & o & $\mathrm{ns}$ \\
\hline Lysine & 77.6 & 84.2 & 78.2 & 78.4 & 82.6 & 79.8 & 1.32 & ns & ns & ns & o & $\mathrm{ns}$ \\
\hline Methionine & 83.7 & 87.2 & 81.9 & 81.7 & 85.0 & 84.2 & 1.17 & ns & ns & o & ns & $\mathrm{ns}$ \\
\hline Phenylalanine & 80.3 & 82.3 & 81.5 & 80.8 & 83.2 & 81.6 & 0.96 & ns & ns & ns & ns & $\mathrm{ns}$ \\
\hline Threonine & 72.7 & 73.3 & 73.3 & 72.8 & 76.4 & 73.2 & 1.26 & ns & ns & ns & ns & ns \\
\hline Valine & 75.9 & 77.8 & 75.7 & 76.0 & 77.8 & 75.3 & 1.21 & ns & ns & ns & ns & $\mathrm{ns}$ \\
\hline \multicolumn{13}{|c|}{ Non-essential amino acids } \\
\hline Alanine & 72.7 & 76.1 & 72.2 & 73.9 & 74.5 & 72.4 & 1.35 & ns & ns & ns & ns & $\mathrm{ns}$ \\
\hline Aspartic acid & 72.8 & 75.8 & 75.8 & 74.9 & 78.4 & 75.3 & 1.48 & ns & ns & ns & ns & $\mathrm{ns}$ \\
\hline Cystine & 77.3 & 81.8 & 74.4 & 74.3 & 71.8 & 73.7 & 3.39 & ns & ns & ns & ns & $\mathrm{ns}$ \\
\hline Glutamic acid & 85.8 & 87.9 & 86.8 & 85.7 & 88.1 & 87.3 & 0.89 & ns & ns & ns & ns & ns \\
\hline Glycine & 72.1 & 69.1 & 73.4 & 71.0 & 70.2 & 68.9 & 2.06 & ns & ns & ns & ns & ns \\
\hline Serine & 76.5 & 78.2 & 78.7 & 78.2 & 80.7 & 77.4 & 1.16 & ns & ns & ns & ns & ns \\
\hline Tyrosine & 79.4 & 80.6 & 80.0 & 79.3 & 81.4 & 78.8 & 0.94 & ns & ns & ns & ns & ns \\
\hline
\end{tabular}

$\mathrm{WB}=$ wheat bran, $\mathrm{WM}=$ wheat middlings, $\mathrm{P}=$ pelleted, $\mathrm{EXP}=$ expanded, $\mathrm{EX}=$ extruded.

1. Contrasts: $\mathrm{C} 1$ : wheat bran diets vs wheat middlings diets (1, 3 and 5 vs 2, 4 and 6); $\mathrm{C} 2$ : extruded diets vs pelleted and expanded diets (5 and 6 vs 1, 2, 3 and 4); C3: pelleted diets vs expanded diets ( 1 and 2 vs 3 and 4); C4:interaction C1*C2; and $\mathrm{C} 5$ :interaction $\mathrm{Cl} * \mathrm{C} 3$.

2. For ileal digestibility, the SEM of diet 1 and 6 is table value multiplied by 1.10 , the SEM of diet 3 table value multiplied by 1.31 and the SEM of diet 2 and 5 table value multiplied by 1.87 . For total tract digestibility the SEM of diets $1,3,4$ and 5 is table value multiplied by 1.17 , and the SEM of diet 2 is table value multiplied by 1.44 .

3. $\mathrm{n}$ for total tract digestibility, see Table 3 .

Significance: $\mathrm{ns}=$ non-significant, $\mathrm{o}=\mathrm{p}<0.10 .^{*}=\mathrm{p}<0.05$ and ${ }^{*}=\mathrm{p}<0.01$.

servations were lacking from the ileal digestibility data because of the difficulty of getting enough ileal digesta from one pig during collections. Otherwise the pigs completed the experiment successfully. The average daily feed intake of the pigs was 92.8 (SE 0.50) g dry matter (DM)/ $\mathrm{kg} \mathrm{W}^{0.75}$ and their average daily weight gain was 919 (SE 19.7) g. No abnormalities caused by cannulation were found in the intestines of the pigs during post-mortem examination.
The experimental diets were designed to contain similar amounts of crude protein (CP) and lysine and NDF. Some fluctuations in contents were, however, found between diets (Table 2). For instance, the $\mathrm{CP}$ and amino acid contents were clearly lower in diet 2 than in the other diets.

Feed processing or dietary wheat by-product had no effect on the apparent ileal or total tract digestibility of CP (Table 3). The average apparent total tract and ileal digestibilities of $\mathrm{CP}$ 


\section{AGRICULTURAL AND FOOD SCIENCE IN FINLAND}

Valaja, J. et al. Effects of feed processing on the apparent ileal digestibility of amino acids

Table 4. Effect of feed processing on nitrogen metabolism of pigs on diets composed of wheat bran or wheat middlings (LS means).



$\mathrm{WB}=$ wheat bran, $\mathrm{WM}=$ wheat middlings, $\mathrm{P}=$ pelleted, $\mathrm{EXP}=$ expanded, $\mathrm{EX}=$ extruded.

1. Contrasts: $\mathrm{C} 1$ : wheat bran diets vs wheat middlings diets (1, 3 and 5 vs 2, 4 and 6); $\mathrm{C} 2$ : extruded diets vs pelleted and expanded diets ( 5 and 6 vs 1, 2, 3 and 4); C3: pelleted diets vs expanded diets ( 1 and 2 vs 3 and 4); 4 :interaction $\mathrm{C} 1$ *C2; and $\mathrm{C} 5$ :interaction $\mathrm{C} 1{ }^{*} \mathrm{C} 3$.

2. The SEM of diets 1,3,4 and 5 is table value multiplied by 1.17. The SEM value of diet 2 is table value multiplied by 1.44 . Significance: $\mathrm{ns}=$ non-significant, $\mathrm{o}=\mathrm{p}<0.10 .{ }^{*}=\mathrm{p}<0.05,{ }^{* *}=\mathrm{p}<0.01$ and ${ }^{* * *}=\mathrm{p}<0.001$.

in the experimental diets were 83.9 and $76.1 \%$, respectively, the difference being $7.8 \%$ units.

Neither were any major differences found in the apparent digestibility of amino acids between feed processing methods or type of wheat byproduct in the diet (Table 3). Diet expanding tended to decrease the apparent ileal digestibility of methionine slightly as compared with pelleting $(\mathrm{p}<0.10)$. Among the essential amino acids in the diets containing wheat by-products, arginine and methionine showed the highest digestibility, ranging from 82.8 to $85.5 \%$ and from 81.7 to $87.2 \%$, respectively and threonine and valine the lowest digestibility, ranging from 72.7 to $76.4 \%$ and from 75.3 to $77.8 \%$, respectively. The highest and lowest digestibilities among the non-essential amino acids were found in glutamic acid and glycine, ranging from 85.7 to $88.1 \%$ and from 68.9 to $72.1 \%$, respectively.

The total tract digestibility of dry matter was higher in diets containing wheat bran than in those containing wheat middlings $(\mathrm{p}<0.01)$. Extruder processing improved the total tract dry matter digestibility as compared with pelleting or expanding, especially in diets containing wheat middlings $(\mathrm{p}<0.05)$. No differences were found in the ileal digestibility of dry matter.

Owing to the variation in the dietary $\mathrm{CP}$ content and lacking observations, the $\mathrm{N}$ intake of the pigs differed significantly between the diets (Table 4). No differences were found in the $\mathrm{N}$ retention of pigs between the diets composed of wheat bran and those composed of wheat middlings. Expanding tended to increase daily $\mathrm{N}$ retention as compared with pelleting $(\mathrm{p}<0.10)$. The level of $\mathrm{N}$ retention per absorption $(\mathrm{p}<0.10)$ and biological value $(\mathrm{p}<0.10)$ tended to be higher in the diets containing wheat middlings than in those containing wheat bran.

\section{Discussion}

One of the aims of feed processing is to enhance the digestibility of dietary nutrients by rupturing the cell wall matrix and modifying the chemical structure of the feed constituents. No such effects were, however, found in the apparent ileal 


\section{AGRICULTURAL AND FOOD SCIENCE IN FINLAND}

Vol. 5 (1996): 557-565.

digestibility of protein and amino acids in either pelleting, expanding or extrusion in the present experiment. This finding is in good agreement with those of earlier studies, which showed that the extrusion, the strongest of the hydrothermal processing methods studied, had very little or no effect on protein and amino acid digestibilities at the ileal level (Fadel et al. 1988, Herkelman et al. 1990, Van der Poel et al. 1990). In the study of Herkelman et al. (1990), extrusion of corn had no effect on the apparent ileal digestibility of amino acids in growing pigs. In addition, Fadel et al. (1988) found that extrusion of barley at $+155^{\circ} \mathrm{C}$ improved non-significantly the apparent ileal digestibility of nitrogen in finishing pigs. The beneficial effects of feed processing on protein digestibility would most probably occur in small piglets, whose digestive system is undeveloped. In early weaned piglets, however, extrusion of maize at $+160^{\circ} \mathrm{C}$ had very little advantage over pelleting in the apparent ileal digestibility of amino acids as only the digestibility of proline and cystine was improved (Van der Poel et al. 1990). In contrast to the above experiments, hydrothermal processing has been reported to improve the apparent ileal digestibility of nitrogen and amino acids in Phaseolus beans by inactivating antinutritional factors such as trypsin inhibitors and lectins (Van der Poel et al. 1991). Our diets, however, did not contain ingredients with a high content of antinutritional substances.

The apparent total tract digestibility of protein in the diets and nitrogen utilisation were also very similar after different processing treatments. This finding, too, is confirmed in earlier studies on growing pigs (Fadel et al. 1988, Herkelman et al. 1990, Näsi 1992) or piglets (Van der Poel et al. 1989, Van Der Poel et al. 1990, Bolduan et al. 1993). In very few experiments comparing diet pelleting and extrusion processes has the apparent total tract digestibility of protein been similar for both processing methods (Patience et al. 1977, Skoch et al. 1983, Tangendjaja et al. 1988). Only Sauer et al. (1990) found that extrusion of a corn-based diet at $+150^{\circ} \mathrm{C}$ improved the total tract digestibility of protein in piglets, by $4.5 \%$ units. This advantage was, however, partially lost when the diets were pelleted after extrusion. Graham et al. (1989) speculated that feed processing might shift digestibility to the upper part of the digestive tract; no such effect on the protein digestibility was detected here, however.

Processing temperatures during expansion were quite low $\left(100-105^{\circ} \mathrm{C}\right)$ in the present experiment and did not cause any differences in protein and amino acid digestibilitities. The very few other studies conducted found, as we did, that the effects of expansion on total tract protein digestibility were minimal (Näsi 1992, Bolduan et al. 1993, Laurinen et al. 1995). Laurinen et al. (1995) reported that expanding led to a slight decrease in the apparent total tract digestibility of protein in one trial but had no effect in another. Here, the tendency towards improved $\mathrm{N}$ retention with expansion was mainly caused by the higher $\mathrm{N}$ supply of the pigs on expanded diets.

Heat treatment, like feed processing, can, however, markedly impair digestibility and utilisation of protein. Increasing heat during extrusion has reduced the availability of lysine mainly because of Maillard reactions with reducing sugars and the $\varepsilon$-amino group of lysine in the feed (Björk and Asp 1983, Pham and Del Rosario 1984). Because only moderate heat was applied during processing in our study, it was unlikely to cause impairment in protein quality.

Amino acids in diets containing wheat bran or wheat middlings were digested similarly at the ileal level. In wheat milling fractions, protein digestibility has declined as the composition of the fraction has changed from endosperm to aleurone to pericarp/testa and the contents of cell walls and dietary fibre have increased (Bach Knudsen and Hansen 1991, Bach Knudsen et al. 1995). Sauer et al. (1977), likewise, found that the apparent ileal digestibility of amino acids and total tract digestibility of protein declined from wheat flour to whole wheat to wheat offals. Moreover, lower ileal amino acid digestibilities have been found in wheat bran than in wheat middlings in a number of trials (Graham et al. 
Valaja, J. et al. Effects of feed processing on the apparent ileal digestibility of amino acids

1986, Lin et al. 1987). In our experiment, however, the dietary inclusion level of both feed fractions was different, and this may have compensated for the differences found in the digestibility of amino acids in both wheat by-products.

Extruder processing improved the total tract digestibility of dry matter in the present experiment, but no differences were found at the ileal level. In contrast to our results, Fadel et al. (1988) and Van der Poel et al. (1990) found that extrusion improved ileal digestibility but not the total tract digestibility of dry matter and organic matter. In the study of Sauer et al. (1990), however, extruder processing improved the total tract digestibility of dry matter.
We conclude, therefore, that neither pelleting, expanding nor extrusion affect the apparent ileal digestibility of amino acids or the total tract digestibility of protein in diets containing wheat bran or wheat middings in growing/finishing pigs. The minor differences found in the protein retention of the pigs were mainly due to differences in $\mathrm{N}$ intake between treatments.

Acknowledgements. We thank Ms Aino Matilainen and the staff of the experimental stable for their technical assistance and for looking after the experimental animals, and Mr Martti Tala operating on the animals. We express our appreciation to Rehuraisio Ltd., Raisio, Finland, for financial assistance.

\section{References}

\begin{abstract}
AOAC. 1984. Official methods of analysis. 14th edition. Association of Official Analytical Chemist. Arlington, Virginia. $1141 \mathrm{p}$.

Bach Knudsen, K.E. \& Hansen, I. 1991. Gastrointestinal implications in pigs of wheat and oat fractions. 1. Digestibility and bulking properties of polysaccharides and other major constituents. British Journal of Nutrition 65 : 217-232.
\end{abstract}

- , Steenfeldt, S., Borsting, C.F. \& Eggum, B.O. 1995. The nutritive value of decorticated mill fractions of wheat. 1. Chemical composition of raw and enzyme treated fractions and balance experiments with rats. Animal Feed Science and Technology 52: 205-225.

Björk, I. \& Asp, N.-G. 1983. The effects of extrusion cooking on nutritional value - a literature review. Journal of Food Engineering 2: 281-308.

Bolduan, G., Beck, M. \& Peisker, M. 1993. Expanderwirkungen auf Ferkelrationen mit Weizenkleie. Kraftfutter No 6: 266-268.

Fadel, J.G., Newman, C.W., Newman, R.K. \& Graham, H. 1988. Effects of extrusion cooking of barley on ileal and faecal digestibilities of dietary components in pigs. Canadian Journal of Animal Science 68: 891-897.

Graham, H., Fadel, J.G., Newman, C.W. \& Newman, R.K. 1989. Effect of pelleting and $\beta$-glucanase supplementation on the ileal and fecal digestibility of a barleybased diet in the pig. Journal of Animal Science 67: 12931298.

- , Hesselman, K. \& Åman, P. 1986. The influence of wheat bran and sugar-beet pulp on the digestibility of dietary components in a cereal-based pig diet. Journal of Nutrition 116: 242-251.

Herkelman, K.L., Rodhouse, S.L., Veum, T.L. \& EIlersieck, M.R. 1990. Effect of extrusion on the ileal and faecal digestibilities of lysine in yellow corn in diets for young pigs. Journal of Animal Science 68: 2414-2424. Laurinen, P., Valaja, J., Näsi, M. \& Smeds, K. 1995. Effects of expanding on the nutritive value of barley and wheat bran in pig diets. Abstract 46th Annual Meeting of the European Association of Animal Production, Prague. No 1: 103.

Lin, F.D., Knabe, D.A. \& Tanksley, T.D., Jr. 1987. Apparent digestibility of amino acids, gross energy and starch in corn, sorgum, wheat, barley, oat groats and wheat middlings for growing pigs. Journal of Animal Science 64: 1655-1663.

Mroz, Z., Bakker, G.C.M., Dekker, R.A., Jongbloed, R. \& Jongbloed, A.W. 1994. Application of the steered ileocaecal valve cannulation (SICV) technique to measure digesta kinetics and ileal digestibility in pigs fed high fibrous diets. In: Souffrant, W.-B. \& Hagemeister, H. (eds). Vith International Symposium on Digestive Physiology in Pigs. Bad Doberan, 4-6th Oktober 1994. Proceedings Vol. 1: 57-59.

Näsi, M. 1992. Effects of grinding, pelleting and expanding on nutritive value of barley in pig diets. Agricultural Science in Finland 1: 461-469.

Patience, J.F., Young, L.G. \& McMillan, I. 1977. Utilization of wheat shorts in swine diets. Journal of Animal Science 45: 1294-1311.

Pham, C.B. \& Del Rosario, R.R. 1984. Studies on the development of texturized vegetable products by the extrusion process. II. Effects of extrusion variables on the available lysine, total and reducing sugars. Journal of Food Science 19: 549-559.

Robertson, J.B. \& van Soest, J. 1981. The detergent system of analysis and its application to human foods. In: James, W.P.T. \& Theander, O. (eds). The analysis of 


\title{
AGRICULTURAL AND FOOD SCIENCE IN FINLAND
}

Vol. 5 (1996): 557-565.

dietary fibre in foods. New York, NY, Marcell Dekker. p. $123-158$.

SAS. 1985. SAS User's Guide: Statistics. 5 th Ed. SAS Institute Inc, Cary, NC, USA. 956 p.

Sauer, W.C., Mosenthin, R. \& Pierce, A.B. 1990. The utilization of pelleted, extruded, and extruded and repelleted diets by early weaned pigs. Animal Feed Science and Technology 31: 269-275.

-, Stothers, S.C. \& Parker, R.J. 1977. Apparent and true availabilities of amino acids in wheat and milling by-products for growing swine. Canadian Journal of Animal Science 57: 775-784.

Skoch, E.R., Binder, S.F., Deyoe, C.W., Allee, G.L. \& Behnke, K.C. 1983. Effects of steam pelleting conditions and extrusion cooking on a swine diet containing wheat middlings. Journal of Animal Science 57: 929-935.

Stanogias, G. \& Pearce, G.R. 1985. The digestion of fibre by pigs. 1 . The effects of amount and type of fibre on apparent digestibility, nitrogen balance and rate of passage. British Journal of Nutrition 53: 513-530.

Tangendjaja, B., Johnson, Z.B. \& Noland, P.R. 1988. Effect of cooking, ensiling, water treatments, extrusion and pelleting on rice bran as feed ingredient for pigs. Nutrition Reports International 37: 939-949.

Tuori, M., Kaustell, K., Valaja, J., Aimonen, E., Saari- salo, E. \& Huhtanen, P. 1995. Rehutaulukot ja ruokintasuositukset. Märehtijät-siat-siipikarja-turkiselăimet-hevoset. Yliopistopaino, Helsinki. 99 p. ISBN 951-46-6971-7. Udén, P., Colucci, P.E. \& Van Soest, P.J. 1980. Investigations of chromium, cerium and cobalt as markers in digesta. Rate of passage studies. Journal of Science of Food and Agriculture 31: 625-632.

Van der Poel, A.F.B., Blonk, J., Huisman, J. \& Den Hartog, L.A. 1991. Effect of steam processing temperature and time on the protein nutritional value of Phaseolus vulgaris beans for swine. Livestock Production Science 28: 305-319.

- , Den Hartog, L.A., Van der Abeele, Th., Boer, H. \& Van Zuilichem, D.J. 1989. Effect of infrared irradiation or extrusion processing of maize on its digestibility in piglets. Animal Feed Science and Technology 26: 29-43.

- , Den Hartog, L.A., Van Stiphout, W.A.A., Bremmers, R. \& Huisman, J. 1990. Effects of extrusion of maize on ileal and faecal digestibility of nutrients and performance of young pigs. Animal Feed Science and Technology 29: 309-320.

Van Kleef, D.J., Deuring, K. \& van Leeuwen, P. 1994. A new method of faeces collection in the pig. Laboratory Animals 28: 78-79.

\section{SELOSTUS}

\section{Prosessoinnin vaikutus vehnän sivutuotteita sisältävien rehuseosten aminohappojen ohutsuolisulavuuteen sioilla}

\author{
Jarmo Valaja, Hilkka Siljander-Rasi ja Markku Mäkinen \\ Maatalouden tutkimuskeskus
}

Rakeistuksen, ekspandoinnin ja ekstruusion vaikutuksia vehnänlesettä tai -rehujauhoa sisältävien dieettien raakavalkuaisen ja aminohappojen ohutsuolisulavuuteen, raakavalkuaisen kokonaissulavuuteen sekä typen hyväksikäyttöön tutkittiin viidellä ohutsuolikanyloidulla lihasialla (elopaino 40-109 kg). Tutkittavina faktoreina olivat rehuseoksen prosessointi (rakeistus, ekspandointi tai ekstruderointi) ja rehun sisältämä myllyteollisuuden sivutuote (vehnänlese tai vehnärehujauho). Ohra ja soijarouhe olivat rehuseoksissa muina raaka-aineina. Lisäksi rehut sisälsivät kivennäisiä, vitamiineja ja puhtaita aminohappoja (lysiiniä ja metioniinia).

Siat kasvoivat hyvin koko kokeen ajan. Keskimääräinen päiväkasvu oli $919 \mathrm{~g}$. Rehun prosessoinnilla tai vehnän sivutuotteella ei ollut vaikutusta raa- kavalkuaisen näennäiseen kokonais- tai ohutsuolisulavuuteen. Raakavalkuaisen kokonaissulavuus oli keskimäärin $83,9 \%$ ja ohutsuolisulavuus $76,1 \%$. Myöskään aminohappojen näennäiseen ohutsuolisulavuuteen eivät prosessointi tai rehun sisältämä vehnänlese tai -rehujauho vaikuttaneet.

Rehuseoksen sisältämä vehnänlese tai vehnärehujauho eivät vaikuttaneet päivittäiseen typen pidättymiseen. Ekspandointi näytti hivenen parantavan typen pidättymistä rakeistukseen verrattuna, vaikkakin tulos johtui lähinnä dieettien välisistä eroista valkuaisen ja aminohappojen saannissa.

Kokeen tulosten perusteella miedolla lämmöllä tapahtuvalla rehun prosessoinnilla ei ole vaikutusta aminohappojen näennäiseen ohutsuolisulavuuteen. 